\title{
EU ASYLUM SYSTEM IN AND AFTER THE COVID-19 PANDEMIC: DISCLOSING THE WEAKNESSES OF THE CURRENT RULES AND ASSESSING THE PROSPECTS OF THE NEW PACT ON MIGRATION AND ASYLUM*
}

\author{
Bojana Čučković, PhD, Associate Professor \\ University of Belgrade Faculty of Law \\ Bulevar kralja Aleksandra 67, Belgrade, Serbia \\ cuckovic@ius.bg.ac.rs
}

\begin{abstract}
The paper analyses the influence that the Covid-19 pandemic has had on the functioning of the European asylum system. The analysis is divided into three parts and addresses problematic issues associated with different stages of the pandemic. In the first part of the paper, the author outlines the asylum practices of EU Member States in the initial stage of the Covid-19 pandemic during which the pandemic was perceived as a state of emergency. By exploring the legal possibilities to derogate both from the EU asylum rules and international human rights standards, the author offers conclusions as regards limits of derogations and the legality of Member States' practices, especially their failure to differentiate between rules that are susceptive of being derogated in emergency situations and those that are not. The second part of the paper analyses the current phase of the pandemic in which it is perceived as a 'new normal' and focuses on making the EU asylum system immune to Covid-19 influence to the greatest extent possible and in line with relevant EU and human rights rules. The author insists on the vulnerability as an inherent feature of persons in need of international protection and researches upon the relationship between the two competing interests involved - protection of asylum seekers and ensuring public health as a legitimate reason for restricting certain asylum seekers' rights. The final part of the paper analyses the prospects of the future EU asylum system, as announced by the New Pact on Migration and Asylum in September 2020, to adapt to the exigencies of both the current Covid-19 crisis and pandemics that are yet to come. With an exclusive focus on referral to Covid-19 and provisions relevant for the current and future pandemics, the author criticizes several solutions included in the instruments that make up the Pact. It is concluded that the Pact failed to offer solutions for problems experienced during the Covid-19 pandemic
\end{abstract}

This paper is the result of research conducted within the scientific project "Pandemic. Law. Society.", supported by the University of Belgrade Faculty of Law. 
and that, under the pretext of public health, it prioritizes the interests of Member States over the interests of applicants for international protection.

Keywords: Asylum, Covid-19, Pandemic, EU, New Pact on Migration and Asylum

\section{INTRODUCTION}

The year 2020 has left the European Union (EU) with two significant legacies that have serious repercussions on its asylum system - the Covid-19 pandemic and the New Pact on Migration and Asylum. ${ }^{1}$

The outbreak of the Covid-19 pandemic put the Common European Asylum System (CEAS) to a difficult test and challenged the already fragile Dublin rules. Under the pretext of emergency measures, Member States introduced a number of changes in the functioning of their asylum systems, thus seriously endangering the rights of the most vulnerable group of persons - those in need of international protection. According to numerous reports of international and European organizations, Member States' responses to Covid-19 varied significantly, both as regards the nature of the measures taken and their temporal scope. However, their common feature seems to have consisted in some sort of suspension of asylum procedures and Dublin transfers, temporary deferral of the right to seek asylum and even, in certain cases, denial of access to the territory. Also, reception conditions in asylum centres were often considered as not in line with measures recommended for the suppression of the pandemic spread, such as over-crowdedness and the consequential impossibility of social distancing.

The paper will analyse the influence of the Covid-19 pandemic on the EU asylum system through three different stages - the initial stage in which Covid-19 was qualified as a state of emergency, the current one which treats Covid-19 pandemic as a 'new normal' and the future stage for which new rules are emerging within the New Pact on Migration and Asylum. As it appears, the documents that make up the Pact take into account the influence of the pandemic both within and beyond the concept of force majeure.

The first part of the paper will focus on the initial stage and the very outbreak of the pandemic during which the pandemic was perceived by the Member States as a state of emergency (2.). A brief overview of various Member States' practices will be provided, followed by an analysis of their legality (2.1.). Legal possibilities to derogate from EU asylum rules will be explored, as well as the limits of deroga-

Communication from the Commission to the European Parliament, the Council, the European Economic and Social Committee and the Committee of the Regions on a New Pact on Migration and Asylum, Brussels, 23 September 2020, COM/2020/609 final. 
tion (2.2.). Being an integral part of a multi-layer system of protection, the CEAS and its functioning during the state of emergency cannot be thoroughly analysed without referring to human rights as a corrective and limiting mechanism. The main claim will consist of Member States' obvious failure to differentiate between those rules that are susceptive of being derogated and those that are not, the principle of non-refoulement and the prohibition of ill-treatment being examples of the latter (2.3.).

The second part of the paper will focus on the functioning of the CEAS in the aftermath of the state of emergency, i.e. the current situation in which the pandemic is no longer perceived as an emergency but rather a 'new normal' (3.). In this context, the application of CEAS rules and standards will be examined in a two-fold manner. Firstly, by balancing between two different aims - the necessity to offer international protection to those in need and the legitimate aim to ensure public health (3.1.). Secondly, by insisting on the vulnerability of persons in need of international protection as the crucial criterion that, instead of allowing for lower standards in the pandemic context, actually requires higher standards to be implemented by the EU Member States in the course of applying the CEAS rules (3.2.).

The third part of the paper will analyse the pandemic in the context of a novelty introduced by the European Commission in September 2020 - the New Pact on Migration and Asylum. Announced as a "fresh start" by the new Commission and its President Ursula von der Leyen, ${ }^{2}$ the Pact was intended to overcome the difficulties encountered by the earlier proposal to reform the Dublin system. Although initially envisaged as a means to respond to the 2015 migrant crisis, it is questionable whether the Pact appropriately acknowledges the current crisis the Covid-19 pandemic (4.). This part of the paper will therefore focus on the pandemic in the future EU asylum system, both within and beyond the concept of force majeure introduced by the Proposal for a Regulation addressing situations of crisis and force majeure in the field of migration and asylum, ${ }^{3}$ and analyse scarce referral to Covid-19 in the documents that make up the Pact (4.1.). The subject matter of a profound analysis will primarily be the practical consequences of an obvious differentiation introduced by Article 1 of the Proposal for a Regula-

2 Press statement by President von der Leyen on the New Pact on Migration and Asylum, Brussels, 23 September 2020, [https://ec.europa.eu/commission/presscorner/detail/en/statement_20_1727], Accessed 5 January 2021.

3 Proposal for a Regulation addressing situations of crisis and force majeure in the field of migration and asylum, Brussels, 23 September 2020, COM(2020) 613 final, 2020/0277(COD) (Proposal for a Regulation on crisis and force majeure). 
tion introducing a screening of third-country nationals at the external borders ${ }^{4}$ between persons who are "vulnerable and in the need of health care" and those "posing a threat to public health". This part of the paper will thus explore whether such a solution, although officially proclaimed to be in the interest of persons in need of international protection, may become yet another basis for protecting the interests of individual Member States (4.2.).

\section{EARLY STAGE - CONSIDERING COVID-19 AS A STATE OF EMERGENCY}

The introduction of the state of emergency, either a formal or a factual one, and consequently the closure of state borders, was the first response to the outbreak of a pandemic caused by the so far unknown virus. This appears to have been a global reaction. ${ }^{5}$ States rather instinctively perceived the virus as an external threat, closed themselves for the rest of the world and turned to internal methods of dealing with the situation. ${ }^{6}$ A nationally oriented response in the area of asylum, however, requires two further observations of a genuinely limiting character. Firstly, though this may be understood as regards the rest of the members of the international community, such a self-centred approach is, to say the least, a surprise when it comes to an integrated group of states that proclaim the principle of solidarity as one of their guiding principles and share common rules and values, Common European Asylum System that consists of a number of legal acts serving as an example. Secondly, asylum seekers and persons in need of international protection become, in times of crisis, even more vulnerable than they already are, which is not properly addressed by states. States primarily focus on the benefit of their nationals whereas the welfare of displaced persons is not perceived as

4 Proposal for a Regulation introducing a screening of third country nationals at the external borders, and amending Regulations (EC) No 767/2008, (EU) 2017/2226, (EU) 2018/1240 and (EU) 2019/817, Brussels, 23 September 2020, COM/2020/612 final, 2020/0278(COD) (Proposal for a Regulation on screening).

5 According to a report prepared by the Danish Refugee Council, 167 countries in the world decided to close their borders, whereas 57 states made no exceptions as regards persons seeking international protection. Danish Refugee Council, A Restriction of Responsibility-Sharing: Exploring the Impact of Covid-19 on the Global Compact on Refugees, Copenhagen, October 2020, p. 11.

6 Russack, S., EU Crisis Response in Tackling Covid-19 - Views from the Member States, European Policy Institutes Network Report, 20 April 2020, p. 1, [https://www.clingendael.org/sites/default/ files/2020-04/Report_EU_crisis_response_April_2020.pdf], Accessed 25 March 2021. Carlucci shares the view and adds that the Union was hesitant to overrule individual EU Member States policies in the field of asylum, which resulted in the ambiguous asylum practices at national levels. Carlucci, M., Europe, Migration and Covid-19: Turning Point or Consolidation of the Status Quo?, International Development Research Network, 2020, pp. 1-11 [https://static1.squarespace.com/static/5e8ce9ff629cbb272fd0406f/t/5ed54e91bd306477f6ca4739/1591037588073/Europe\%2C+Migration+and+Covid-19.pdf], Accessed 14 January 2021. 
a priority, ${ }^{7}$ even recognizing them as "a threat to the national well-being" thus

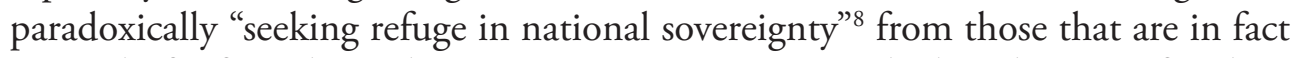
in need of refuge themselves. Emergency measures applied in the area of asylum differed from one EU Member State to another (2.1.). However, there are serious concerns regarding the legality of these measures, both from the perspective of EU asylum law and EU law in general (2.2.), as well as their compatibility with recognized international human rights standards (2.3.).

\subsection{EU Member States' practices regarding asylum after the outbreak of the Covid-19 pandemic - a brief overview of emergency measures}

Although the need for a common approach was recognized and stressed by the European Council on 10 March 2020, ${ }^{9}$ whereas the European Commission adopted a Communication providing for temporary restriction of non-essential travel to the EU due to Covid-19, which explicitly excluded "persons in need of international protection or for other humanitarian reasons", ${ }^{10}$ the practices of EU Member States were quite different, certifying that in emergency times examples of bad practices outweigh the good ones. According to available information, Portugal was among rare states to grant citizenship rights to all asylum seekers whose applications were still under consideration at the time, with the main aim to allow this category of persons access to social security and health care. ${ }^{11}$ Spain decided not to require asylum seekers to have valid documents to receive aid and health care and released migrants from administrative detention due to the impossibility

7 Jauhiainen, J., Biogeopolitics of Covid-19: Asylum-Related Migrants at the European Union Borderlands, Tijdschrift voor Economische en Sociale Geografie, Vol. 111, No. 3, 2020, p. 261.

8 Triandafyllidou, A., Commentary: Spaces of Solidarity and Spaces of Exception at the Times of Covid-19, International Migration, Vol. 58, No. 3, 2020, p. 261.

9 Conclusions by the President of the European Council following the video conference on COVID-19. 10 March 2020, [https:/www.consilium.europa.eu/en/press/press-releases/2020/03/10/statement-by-the-president-of-the-european-council-following-the-video-conference-on-covid-19/], Accessed 6 March 2021.

10 Communication from the Commission to the European Parliament, the European Council and the Council, Covid-19: Temporary Restriction on Non-Essential Travel to the EU, Brussels, 16 March 2020, COM/2020/115 final. One month later, the Commission adopted another relevant Communication relating to implementation of EU asylum rules in the context of Covid-19. Communication from the Commission COVID-19: Guidance on the implementation of relevant EU provisions in the area of asylum and return procedures and on resettlement 2020/C 126/02, C/2020/2516, OJ C 126, 17.4.2020, pp. 12-27.

11 Dimitriadi, A., The Future of European Migration and Asylum Policy post Covid-19, FEPS Covid Response Papers, Issue No. 7, July 2020, p. 4 [https://www.feps-europe.eu/attachments/publications/ feps\%20covid\%20response\%20migration\%20asylum.pdf], Accessed 12 January 2021. 
to fully implement epidemiological measures in detention institutions. ${ }^{12}$ Luxembourg automatically extended the status of persons whose asylum applications were underway, while Germany and Sweden allowed persons in need of international protection to both enter their territories and submit asylum applications. ${ }^{13}$ Contrary to examples of good practices, measures taken in the other EU Member States were problematic and proved that covid-19 emergency measures "have affected the way states implement European law provisions and related administrative procedures on asylum, return and resettlement". ${ }^{14}$ Hungary and Greece denied entry to persons seeking asylum ${ }^{15}$ and suspended the right to apply for asylum, Italy and Malta declared their ports to be unsafe for disembarkation thus denying access to both territory and asylum procedures to newly arrived migrants, whereas Belgium and the Netherlands closed their arrival centres. ${ }^{16}$ Pushbacks, a flagrant violation of the non-refoulement principle, were reported both on seas in Cyprus and Greece ${ }^{17}$ and on land in Croatia. ${ }^{18}$ The closure of internal borders seriously influenced one of the basic Dublin mechanisms - the so-called Dublin transfers which were suspended in the Netherlands, Germany and some other EU Member States. ${ }^{19}$ The situation in Greece, besides problems regarding unsanitary conditions in overcrowded asylum centres on Greek islands, ${ }^{20}$ also serves as a failed example of EU solidarity concerning the most vulnerable category of persons in need of international protection - the unaccompanied minors. Although the European Commission proposed a scheme for relocation of unaccompanied minors

12 Ibid. However, in another aspect, measures adopted by Spain are problematic. Since it officially declared the state of emergency, Spain suspended the right to apply for asylum. Marin. L., The Covid-19 Crisis and the Closure of External Borders: Another Stress-test for the Challenging Construction of Solidarity Within the EU?, European Papers, Vol. 5, No. 2, 2020, p. 1077.

13 International Commission of Jurists, The Impact of Covid-19 related measures on human rights of migrants and refugees in the EU, Briefing paper, 26 June 2020, p. 3, [https://www.icj.org/wp-content/uploads/2020/06/Covid19-impact-migrans-Europe-Brief-2020-ENG.pdf], Accessed 14 January 2021.

14 Marin, op. cit., note 12, pp. 1075-1076.

15 International Commission of Jurists, op. cit., note 13, p. 2.

16 Marin, op. cit., note 12, pp. 1077-1078.

17 International Commission of Jurists, op. cit., note 13, p. 2.

18 Danish Refugee Council, op. cit., note 5, pp. 25-26.

19 International Commission of Jurists, op. cit., note 13, p. 6.

20 Veizis, A., Commentary: "Leave No One Behind" and Access to Protection in the Greek Islands in the Covid-19 Era, International Migration, Vol. 58, No. 3, 2020, p. 265. Problems regarding reception conditions, lack of respect for basic epidemiological measures and restrictions on movement were reported in other EU countries: International Commission of Jurists, op. cit., note 13, pp. 12-13, 17; European Council on Refugees and Exiles, Covid-19 Measures related to Asylum and Migration across Europe, Information Sheet No. 8, April 2020, pp. 4-5. For a situation in France's Calais settlements, see: Danish Refugee Council, op. cit., note 5, p. 11. 
from Greece to the other EU Member States, ${ }^{21}$ only ten states announced to take their share in the relocation. ${ }^{22}$

This brief overview of EU Member States' responses to Covid-19 in the area of asylum leads to a conclusion of an obvious lack of any coordination at the EU level that, as noted by Kelly, "seriously undermined the legitimacy of seeking asylum within the EU". ${ }^{23}$ It is questionable whether such diversity in applying CEAS in the context of Covid-19 pandemic may be understood as an adaptation to the exigencies of the pandemic within the EU system or they instead prove that the CEAS does not offer an appropriate legal framework for taking coherent measures at the Union level in pandemic times. Covid-19, despite the mentioned Communication of the European Commission on non-essential travel that explicitly excluded persons in need of international protection, obviously served the EU Member States as an excuse for either entirely or partly suspending the CEAS rules and standards. However, although such emergency measures may be explained by factual reasons, it remains to be seen whether there was a legal basis for their introduction and whether there was a red line that was not supposed to be crossed even in times of emergency.

\subsection{DEROGATING FROM CEAS - LEGAL POSSIBILITIES}

Potential grounds for derogation from CEAS rules may be located both in primary EU law and relevant sources of secondary EU law.

The area of freedom, security and justice of which asylum forms an integral part, is regulated by rules contained in the Title $\mathrm{V}$ of the Treaty on the Functioning of the European Union (TFEU). ${ }^{24}$ Article 72 TFEU has already been invoked by the Member States as a legal basis not to apply EU asylum law in emergency situations. ${ }^{25}$ In joined cases C-715/17, C-718/17 and C-719/17, Poland and Hungary claimed that "they were entitled under Article 72 TFEU, (...) to disapply their

$21 \quad$ Migration: Commission takes action to find solutions for unaccompanied migrant children on Greek islands, European Commission, Press release, Brussels, 6 March 2020 [https://ec.europa.eu/commission/presscorner/detail/en/ip_20_406], Accessed 10 February 2021.

22 Dimitriadi, op. cit.., note 11, p. 5.

23 Kelly, S.B., The European Union Obligation: Member States must not Neglect the Consequences of Covid-19 to the Disadvantaged Asylum Seekers and Refugees, HAPSc Policy Briefs Series, Vol. 1, No. 1, 2020, p. 215.

24 Consolidated version of the Treaty on the Functioning of the European Union [2012] OJ C 326, pp. 47-390 (TFEU).

25 Article 72 TFEU provides that title $\mathrm{V}$ "shall not affect the exercise of the responsibilities incumbent upon Member States with regard to the maintenance of law and order and the safeguarding of internal security". 
secondary, and therefore lower-ranking, legal obligations". ${ }^{26}$ However, the Court of Justice of the European Union (CJEU) clearly stated that it cannot be inferred "that the Treaty contains an inherent general exception excluding all measures taken for reasons of law and order or public security from the scope of European Union law" since "the recognition of the existence of such an exception, regardless of the specific requirements laid down by the Treaty, might impair the binding nature of European Union law and its uniform application". ${ }^{27}$ Instead, the Court suggests that Member States cannot rely on Article 72 as a basis for derogation in case "provisions contained in secondary law are sufficient to address State security interests, and are most appropriate to ensure that the objectives of the acquis are met". ${ }^{28}$

Two questions are raised in the specific context of Covid-19. Firstly, can Covid-19 situation be qualified as a threat for "the maintenance of law and order and the safeguarding of internal security" as required by Article 72 and, secondly, whether CEAS rules, as relevant secondary legislation, ensure in an appropriate manner EU Member States' interests threatened by Covid-19 pandemic in the context of asylum?

Public health, although not expressly mentioned in Article 72, may be considered to be encompassed by Article 72 using two arguments. On the one hand, the CJEU itself adopted a rather extensive reading of the term security and considered that it included situations of "fundamental importance for a country's existence, not only its economy but above all its institutions, its essential public services and even the survival of its inhabitants". ${ }^{29}$ On the other hand, specific secondary legislation in the area of freedom, security and justice, such as the Schengen Borders Code, recognizes public health among grounds for not allowing entry to third-country nationals. ${ }^{30}$ However, and this is of crucial importance for considering the legality of asylum-related emergency measures taken by the EU Member States in the state of the emergency phase of the pandemic, security reasons cannot

26 Joined Cases C715/17, C718/17 and C719/17 Commission v. Poland, Hungary and Czech Republic, [2020] ECLI:EU:C:2020:257, par. 134.

27 Ibid., par. 143.

28 European Council on Refugees and Exiles, Derogating from EU Asylum Law in the Name of "Emergencies": The Legal Limits Under EU Law, Legal Note No. 6, 2020, pp. 2-3. Such a conclusion can be drawn from paras. 150-156 of CJEU judgment in the already mentioned joined cases C715/17, C718/17 and C719/17.

29 Case 72/83 Campus Oil Limited and others v Minister for Industry and Energy and others [1984] ECR $1984-02727$, par. 34.

30 Article 6 (1, e) of the Regulation (EU) 2016/399 of the European Parliament and of the Council of 9 March 2016 on a Union Code on the rules governing the movement of persons across borders (Schengen Borders Code) [2016] OJ L 77, pp. 1-52. 
be invoked by the Member States on their own and in a unilateral manner. They thus cannot be taken "without any control by the institutions of the European Union". ${ }^{31}$

The answer to the second question is not clear. It may be inferred from the position taken by the Commission in its Communication relating to Covid-19 which provided EU Member States with guidance on the implementation of relevant EU provisions in the area of asylum. ${ }^{32}$ To prevent and contain the spread of Covid-19, the Commission recognizes general "public health measures such as medical screening, social distancing, quarantine and isolation" as applicable for applicants for international protection, "provided that these measures are reasonable, proportionate and non-discriminatory". ${ }^{33}$ In other words, although aware that the pandemic has a disruptive effect on the way EU asylum rules are implemented by the Member States, the Commission stresses that such a situation is capable of being overcome through public health measures and that Covid-19 cannot in itself be considered a security reason that would require to derogate from CEAS. However, a counter-argument may also be offered. Namely, the Commission stresses in its Communication that "only the European Court of Justice may give authoritative interpretations of Union law". ${ }^{34}$ It also notices that "a situation such as the one resulting from the Covid-19 pandemic has not been foreseen" in legal acts that comprise the CEAS. ${ }^{35}$ It may thus be argued that the specificities of a pandemic as a unique security threat have not been properly taken into account within the secondary legislation and that therefore Article 72 TFEU may be used as a basis for derogating from CEAS since it does not sufficiently address Member States' interests. Although the author tends to consider the first option as more in line with the very nature, structure and aims of the CEAS, the further interpretation of Article 72 TFEU will hopefully be given by the Court in its future judgments.

The potential legal basis for derogation at the level of EU secondary legislation is easier to consider. The Commission seems to place on equal footing the 2015 crisis concerning a large number of simultaneous applications and the one caused by the Covid-19 pandemic and it considers that the same derogatory rules would apply to both situations. ${ }^{36}$ In other words, the Covid-19 pandemic did not require the suspension and derogation of CEAS in general, but a degree of flexibility

\footnotetext{
31 Commission v. Poland, Hungary and Czech Republic, par. 146.

32 Communication Covid-19, note 10.

33 Ibid., p. 12.

34 Ibid.

35 Ibid., p. 13.

36 Communication Covid-19, note 10, p. 13.
} 
that needed to stay within CEAS standards and only to the extent allowed by the derogatory and discretionary clauses contained therein. To be more precise, flexibility is allowed concerning time limits set by the Asylum Procedures Directive, ${ }^{37}$ the conditions to apply the so-called sovereignty or discretionary clause contained in the Dublin III Regulation ${ }^{38}$ or options offered by the Reception Conditions Directive regarding material reception conditions. ${ }^{39}$ Also, provisions of the Reception Conditions Directive concerning health care are to be interpreted as encompassing Covid-19 related care.

It may be concluded that it is highly questionable whether Covid-19, qualified as a threat to the maintenance of law and order and the safeguarding of internal security, met the requirements for applying Article 72 TFEU as a legal basis for emergency measures in the area of asylum. Therefore, derogatory provisions already contained in the CEAS instruments offered in the emergency phase the only possible ground for adapting the national asylum systems to the circumstances caused by the Covid-19 pandemic.

\subsection{CEAS as an integral part of a multi-layer system of protection - human rights as a limiting and corrective mechanism}

Since all EU Member States are at the same time contracting parties to the European Convention on Human Rights and Fundamental Freedoms (ECHR), the measures taken during the state of an emergency stage of the pandemic must also be examined with regard to the obligations and standards that exist within the ECHR system of protection..$^{40}$ ECHR, through its Article 15, as well as the European Court of Human Rights (ECtHR) through its case-law on the matter, actually offer clear guidance as to which line should not be crossed even in cases when the pandemic

37 Articles 6(5) and 31(3) of the Directive 2013/32/EU of the European Parliament and of the Council on common procedures for granting and withdrawing international protection [2013] OJ L 180, pp. 60-95.

38 Article 17 of Regulation (EU) No 604/2013 of the European Parliament and of the Council establishing the criteria and mechanisms for determining the Member State responsible for examining an application for international protection lodged in one of the Member States by a third-country national or a stateless person (recast) [2013] OJ L 180, pp. 31-59.

39 Article 18 of the Directive 2013/33/EU of the European Parliament and of the Council laying down standards for the reception of applicants for international protection (recast) [2013] OJ L 180, pp. 96-116.

40 Such an overlap of different legal system in the area of asylum that include also the EU Charter on Fundamental Rights is considered as "multi-dimensionality of constitutional protection of human rights". Ippolito, F.; Velluti, S., The Relationship between the CJEU and the ECtHR: the Case of Asylum, in: Dzehtsiarou, K.; Konstadinides, T.; O’Marea, N. (eds), Human Rights Law in Europe - The Influence, Overlaps and Contradictions of the EU and the ECHR, Routledge, 2014, p. 156. 
reaches the level that can be qualified as "an exceptional situation of crisis or emergency which affects the whole population and constitutes a threat to the organized life of the community of which the State is composed". ${ }^{41}$ Authors that have so far dealt with the issue tend to consider Covid-19 as meeting the requirements of an emergency and that therefore, ECtHR's case law, although so far concerned with terrorist activities, armed conflicts and military coups, can be applied to the Covid-19 situation. ${ }^{42}$ However, and in line with the ECtHR's position in its 2020 Judgment in the case Başv Turkey, the Covid-19 pandemic may be considered to have fulfilled the conditions of a state of emergency only in the initial stage of the pandemic analyzed in this section of the paper, whereas with time its characteristics evolved thus making the public emergency considerations less obvious and of a declined intensity, requiring the exigency criterion to be applied "more stringently". ${ }^{43}$

Difficulties faced by the EU Member States in fulfilling their duties towards asylum seekers due to Covid-19 may have led to certain modalities and adaptations. However, to be considered compatible with ECHR standards, national emergency measures in the field of asylum couldn't have impacted the enjoyment of absolute rights, such as the prohibition of ill-treatment provided by Article 3 ECHR and non-refoulement. It may therefore be concluded that no measures limiting access to the territory for persons in need of international protection can be considered as legal and required by the exigencies of the situation, whereas the same would apply to reported cases of push-backs and detention and reception conditions that may be qualified as meeting the minimum level of severity required by Article 3 ECHR. ${ }^{44}$ In other words, human rights of absolute nature represent an ultimate limit that cannot be crossed under any circumstances, no matter how extraordinary they are. Such a conclusion carries a dual meaning - general and individual. From the perspective of the (mal)functioning of the entire system, Covid-19 couldn't serve the purpose of derogating from both national and EU rules in the area of asylum, due to difficulties in meeting EU Member States' obligations. Among many rules that may be adapted to the exigencies of the situation, duties of absolute nature such as non-refoulement and prohibition of ill-treatment in its

41 Judgment Lawless v Ireland No. 3 (1961) 1 EHRR 15, par. 28.

42 Jovičić, S., Covid-19 Restrictions on Human Rights in the Light of the Case-law of the European Court of Human Rights, ERA Forum, Vol. 21, 2021, p. 550; Spadaro, A., Covid-19: Testing the Limits of Human Rights, European Journal of Risk Regulation, Vol. 11, No. 2, 2020, p. 321.

43 Judgment Başv Turkey (2020), par. 224.

44 Both European Asylum Office and the Fundamental Rights Agency pointed to concerns that EU Member States' practices in the field of asylum can be considered as incompatible with non-derogable human rights. European Asylum Support Office, Covid-19 Emergency Measures in Asylum and Reception Systems, Issue No. 2, 15 July 2020, pp. 7-8; Fundamental Rights Agency, Coronavirus Pandemic in the EU-Fundamental Rights Implications, Bulletin No. 1, April 2020, pp. 24-25, 29. 
various appearances, cannot be either derogated from or adapted no matter how difficult the situation faced by the State in question may be. ${ }^{45}$ From an individual asylum seeker's point of view, his or her state of health cannot serve as an excuse for not offering him/her access to territory and adequate protection, again in case there is a risk of refoulement or ill-treatment. Even though EC Covid-19 Guidelines for border management measures to protect health and ensure the availability of goods and essential services allows the Member States "to refuse entry to nonresident third-country nationals where they present relevant symptoms or have been particularly exposed to risk of infection and are considered to be a threat to public health", it is also suggested that alternative measures "such as isolation or quarantine may be applied". ${ }^{46}$ In any case, when persons in need of international protection are concerned, and in line with both the Schengen Borders Code and the Communication on non-essential travel, international obligations have precedence and exceptions are not applicable. This means that when denial of access to territory may be qualified as amounting to refoulement, Member States have duties towards persons facing the risk of persecution or serious harm, and to assess the existence of an individualized risk, access to both the territory and procedures must be guaranteed regardless of any considerations concerning public health. ${ }^{47}$ The same dual approach applies to other EU Member States practices that might have been qualified as violations of absolute rights, reception and living conditions as well as immigration detention serving as examples. Neither general difficulties the Member State is facing due to Covid-19, nor the fact that the person represents a risk for public health may serve as valid excuses for not complying with the standards set by the ECtHR in its Article 3 jurisprudence. ${ }^{48}$

45 The Commission itself does not question such an interpretation of the EU asylum rules in the context of Covid-19 pandemic. It stresses that "any restrictions in the field of asylum, return and resettlement must (...) take into account the principle of non-refoulement and obligations under international law”. Communication Covid-19, note 10, p. 12.

46 European Commission, Covid-19 Guidelines for border management measures to protect health and ensure the availability of goods and essential services (2020) OJ C 86/I, p. 3.

47 Crawley, H., The Politics of Refugee Protection in a (Post)Covid-19 World, Social Sciences, Vol. 10, 2021, p. 5.

48 In addition to abundant ECtHR case-law through which clear standards have been established regarding the conditions in asylum and migrant centres that States need to meet in order not to qualify them as violation of the prohibition of torture, inhuman and degrading treatment, the latest Rule 39 provisional measure indicated by the ECtHR with regard to Greece proves that same standards are applicable in the pandemic context. Namely, on 16 April 2020 ECtHR ordered provisional measures in the case E.I. and others $v$ Greece consisting in immediate transfer of vulnerable people from Moria camp where they faced serious health risks due to poor conditions. Tsourdi, E., Covid-19, Asylum in the EU, and the Great Expectations of Solidarity, International Journal of Refugee Law, Vol. 32, No. 2, 2020, p. 377. For ECtHR case-law that concerns reception conditions of asylum seekers in the context of Article 3, see: N. $v$ the United Kingdom (2008), Tabesh v Greece (2009), Louled Massoud v Malta (2010), M.S.S. v Belgium and Greece (2011), Sharifi and others v Italy and Greece (2014), Tarakhel v Switzerland (2014). 


\section{CURRENT SITUATION - CEAS AND COVID-19 AS A 'NEW NORMAL'}

With the continuous presence of Covid-19 and the impossibility of still perceiving it as an 'imminent' threat, the situation has emerged into a 'new normal' or 'new reality'. ${ }^{49}$ This phase may be considered to have commenced in June 2020 when the initial strict lock-downs in numerous EU countries started to soften and the emergency phase was considered to be over. However, the situation did not imply the return to the one that existed before the outbreak of the pandemic. It instead indicated that the EU asylum system needed to continue to function in the newly emerging circumstances where the virus was still present and exerted a strong influence. However, instead of derogations of both EU rules and human rights obligations, only certain limitations due to public health reasons seem to be an option in the second phase. This part of the paper will therefore focus on making the asylum system "Covid-19 proofed" 50 to the greatest extent possible and in line with relevant EU and human rights rules. To avoid using Covid-19 as an excuse for evading States' "responsibilities towards refugees under international law and for introducing even more restrictive policies that may well become (semi)permanent once the pandemic is over", ${ }^{51}$ two issues are of relevance. Firstly, it is important to explore the relationship between the two competing interests involved - protection of asylum seekers and ensuring public health, since public health does represent a legitimate reason for restricting certain asylum seekers' rights (3.1.). Secondly, the focus should be on the consequences that vulnerability as the main feature of asylum seekers as a group may have on standards that apply in the present stage of the pandemic (3.2.).

\subsection{Weighing between public health and international protection}

In the current phase, the pandemic seems not to fulfil one of the four criteria required by the ECtHR to be qualified as an emergency. ${ }^{52}$ Namely, it does not appear to be "exceptional, in that the normal measures or restrictions, permitted

49 Danish Refugee Council, op. cit., note 5, p. 6. Arnoux-Bellavitis, M., The Influence of Covid-19 on the European Asylum and Migration Policy - Making Health a Priority while Ensuring the Respect for Fundamental Rights, Institute of European Democrats, 2020, p. 5, [https://www.iedonline.eu/download/ geopolitics-values/26-Arnoux-Bellavitis_-_The_influence_of_covid_19_on_the_EU_asylum_and_ migration_policy-FINAL.pdf], Accessed 1 April 2021.

50 Rasche, L., Four Implications of the Covid-19 Pandemic for the EU's Asylum and Migration Policy, Policy Brief, 24 July 2020, p. 5, [https://www.hertie-school.org/fileadmin/2_Research/1_About_our_research/2_Research_centres/6_Jacques_Delors_Centre/Publications/20200724_Covid-19_Migration-Rasche.pdf], Accessed 25 March 2021.

51 Crawley, op. cit., note 47, p. 7

52 Denmark, Norway, Sweden and the Netherlands v. Greece (1968), par. 113. 
by the Convention for the maintenance of public safety, health and order, were plainly inadequate". ${ }^{33}$ Under such circumstances, the derogable rights of asylum seekers can be interfered with by a public authority, provided that the interference is in accordance with the law, necessary in a democratic society and in the interest, inter alia, of protecting public health. Public health can thus be considered as a legitimate aim in pursuance of which rights of asylum seekers can be restricted. However, and this is of crucial importance, a fair balance would need to be struck between an individual's interest to have his rights protected and general interest to ensure public health. This weighing between the two competing interests appears to be the most difficult aspect in the current phase of the pandemic. Both states and judicial bodies, national and international, will face the difficulty of assessing "whether the extraordinary measures taken during the Covid-19 period have been adequate and proportionate response to the situation", ${ }^{54}$ or whether it was possible to achieve the same aim through less stringent measures. The lawfulness and proportionality tests will thus become the most relevant standards for assessing the compatibility of EU Member States' asylum practices and measures in the current stage of the pandemic. The proportionality test allows for certain adaptation to the particular circumstances of each Member State, ${ }^{55}$ while at the same time precluding it from adopting approaches of general character since the assessment needs to be carried out in each particular case by taking into account the individual situation of a person in question. In other words, any restrictive measure needs to be assessed from the perspective of its necessity in the pandemic context and the need to protect public health. However, this should by no means be disproportionate to the standards that apply to persons in need of international protection established by both CEAS and international law. These considerations once again prove the inseparability of the CEAS from international human rights standards and suggest that "the human rights dimension needs to be at the heart of the European policy on migration and asylum, particularly in a post-Covid-19 world" ${ }^{56}$ Although the Covid-19 pandemic is perceived as a 'new normal', the same should be avoided when human rights restrictions are concerned. As correctly noted by Spadaro, to

$53 \quad$ Ibid.

54 Jovičić, op. cit., note 42, p. 559. Tzevelekos and Dzehtsiarou expect the ECtHR to offer relevant criteria in its future jurisprudence: Tzevelekos, V.; Dzehtsiarou, K., Normal as Usual? Human Rights in Times of Covid-19, European Convention on Human Rights Law Review, Vol. 1, 2020, pp. 145-146.

55 Rasche considers that protection of public health may be achieved through adaptation of certain CEAS procedural rules, such as introducing online registration, remote management of applications or video interviewing, as well as preparing reception centers in a way to ensure sanitary and epidemiological requirements. Rasche, op. cit., note 50, p. 5. Proportionate restrictions may also be introduced with regard to provisions that concern the freedom of movement or family unity of persons in need of international protection. International Commission of Jurists, op. cit., note 13, pp. 7-8, 17-19.

56 Dimitriadi, op. cit., note 11, p. 8. 
prevent that "the curtailment of human rights" becomes "the new normal, States should strive to adopt a long-term strategy for the management of the pandemic that does not rely on the continued restriction" of fundamental rights. ${ }^{57}$

\subsection{Vulnerability of asylum seekers as a criterion requiring higher instead of lower standards of protection in times of pandemic}

Vulnerability as an inherent characteristic of persons in need of international protection has a three-fold influence on CEAS rules in the current phase of the Covid-19 pandemic. ${ }^{58}$ Firstly, it serves as a limiting factor in the context of introducing potential restrictive measures for the protection of public health. Secondly, it is an emerging factor to be taken into consideration while applying existing rules. Thirdly, vulnerability requires the rising of existing standards, especially as regards health care and protection of the health of persons in need of international protection.

Restrictive measures affect persons in need of international protection to a greater extent than other groups that are not inherently vulnerable. ${ }^{59}$ Namely, as noted by the Danish Refugee Council, European Asylum Support Office, as well as other organizations and institutions, lockdowns and restrictions on freedom of movement might lead to "risk of starvation", "lack of regular deliveries of food and water", "limited assistance" and "increased insecurity", ${ }^{60}$ as well as an "increased risk of contracting diseases, including Covid-19". ${ }^{61}$ The same applies as regards restrictions to other derogable rights. Due to their vulnerability, asylum seekers are impacted by such restrictions in a more striking and consequential manner than the rest of the population. Such a discrepancy in the Covid-19 restrictive measures' influence must therefore be taken into account as a decisive factor when adopting

$57 \quad$ Spadaro, op. cit., note 42, p. 323.

58 In addition to the well-established case-law of the ECtHR which consistently qualifies persons in need of international protection as a vulnerable group (MSS v Belgium and Greece [GC] (2011) 53 EHRR 2, par. 251), in the specific context of the Covid-19 pandemic the World Health Organization identified the refugees as one of the most adversely affected populations. Alemi, Q., Stempel, C., Siddiq H. \& Kim, E., Refugees and COVID-19: achieving a comprehensive public health response, Bulletin of the World Health Organization, Vol. 98, 2020, 510.

59 Lanzarone, A.; Tullio, V.; Argo, A.; Zerbo, S., When a Virus (Covid-19) Attacks Human Rights: The Situation of Asylum Seekers in the Medico-Legal Setting, Medico-Legal Journal, Vol. 89, No. 1, 2021, p. 29.

60 Danish Refugee Council, op. cit., note 5, p. 11; European Asylum Support Office, op. cit., note 44, p. 7.

${ }_{61}$ Kluge, H. H.; Jakab, Z.; Bartovic, J.; D’Anna, V.; Severoni, S., Refugee and Migrant Health in the Covid-19 Response, The Lancet, Vol. 395, 2020, p. 1238. 
them, ${ }^{62}$ whereas they should be tailored according to the specific characteristics of persons in need of international protection in order to avoid that Covid-19 vulnerabilities turn into "an extrapolation of already existing vulnerabilities". ${ }^{63}$ In other words, the vulnerability of asylum seekers requires Covid-19 restrictive measures to be specific, not too invasive and, to the extent needed, to differ from general measures applied to the rest of the population.

Certain specific issues may emerge in the context of applying the CEAS in the current pandemic context. Namely, Covid-19 might also emerge as a factor to be taken into account concerning assessing the safety of a country to which the person is to be returned, either in the context of Dublin transfers, or the return of a failed asylum seeker to his/her country of origin or a third safe country. In other words, should the difficult epidemiological situation in the country to which the person is supposed to be returned in accordance with CEAS rules, be considered the reason not to return the person in question? Judging by the existing case-law of both the ECtHR ${ }^{64}$ and the CJEU, ${ }^{65}$ malfunctioning of the asylum system and poor reception conditions in the country to which the person is to be returned indeed should be considered as decisive. ${ }^{66}$ Although established in the context of a massive influx of asylum seekers, there is no reason why the same standards should not apply in case the asylum system is not functioning properly because of the pandemic or the reception conditions in the country to which the person is to be returned to may be qualified as meeting the minimum level of severity required by the prohibition of inhuman or degrading treatment. It thus appears that Covid-19

62 Guadagno correctly remarks that "crisis response measures cannot effectively include migrants unless they proactively address underlying conditions of vulnerability linked with migratory status". Guadagno, L., Migrants and the Covid-19 Pandemic: An Initial Analysis, Migration Research Series No. 60, International Organization for Migration, Geneva, 2020, p. 13. The same argument applies to asylum seekers and persons in need of international protection, the most vulnerable category of migrants.

63 Mukumbang, F., Are Asylum Seekers, Refugees and Foreign Migrants Considered in the Covid-19 Vaccine Discourse?, BMJ Global Health, 2020, p. 2.

64 MSS v Belgium and Greece [GC] (2011) 53 EHRR 2, paras. 344-359.

65 Case C-411/10 N. S. $v$ Secretary of State for the Home Department and Case C-493/10 M. E. and Others $v$ Refugee Applications Commissioner and Minister for Justice, Equality and Law Reform [2011] ECR I-13905, par. 106.

66 For a detailed analysis of the jurisprudence of CJEU and ECtHR in this context see: Lukić-Radović, M.; Čučković, B., Dublin IV Regulation, the Solidarity Principle and Protection of Human Rights Step(s) Forward or Backward?, in: Duić, D.; Petrašević, T., (eds), EU Law in Context - Adjustment to Membership and Challenges of the Enlargement, EU and Comparative Law Issues and Challenges Series, University Josip Juraj Strossmayer, Osijek, 2018, pp. 15-22; Rizcallah, C., Facing the Refugee Challenge in Europe: A Litmus Test for the European Union - A Critical Appraisal of the Common European Asylum System Through the Lens of Solidarity and Human Rights, European Journal of Migration and Law, Vol. 21, No. 2, pp. 251-254 
will influence the CEAS in an additional manner - by introducing a novel factor to be considered when adopting transfer and return decisions.

Finally, the Covid-19 pandemic may also be expected to raise standards, particularly those that relate to reception and detention conditions, as well as health care of asylum seekers. As noted earlier, reception conditions will have to be altered as a consequence of the pandemic, especially as regards density of the population in asylum and immigration detention centres, sanitary conditions, the necessity to relocate persons from the centres in cases of over crowdedness and health screenings, both upon arrival and on regular basis. Furthermore, it has already been confirmed by the European Commission that relevant provisions contained in the Receptions Conditions Directive concerning health care should be interpreted as including treatment for Covid-19. ${ }^{67}$ Finally, within asylum seekers as a vulnerable group, enhanced protection should be accorded to vulnerable subgroups. ${ }^{68} \mathrm{In}$ addition to well-established vulnerable subgroups of asylum seekers such as unaccompanied minors, pregnant women and elderly people, the Covid-19 pandemic may result in including on this list also persons with health issues that have been proven to represent an additional risk in case of Covid-19 infection. In this context, health screenings upon reception in asylum centres should become more thorough and include not only screening for Covid-19 but also other chronic health conditions considered as potential comorbidities. ${ }^{69}$ The tendency to raise standards of protection in order to mitigate the adverse consequences of the pandemic can also be recognized in the European Centre for Disease Prevention and Control Guidance on migrant and refugee reception and detention centres, ${ }^{70}$ whereas it is to be expected that further raising of standards will ensue with future applications before the relevant international judicial and quasi-judicial institutions.

\section{FUTURE OF THE EU ASYLUM SYSTEM -PANDEMIC AS A CRISIS, FORCE MAJEURE OR A HEALTH ISSUE?}

The final section of the paper will analyse the prospects of the future EU asylum system, as announced by the New Pact on Migration and Asylum, to adapt to the exigencies of both the current Covid-19 crisis and pandemics that are yet to

67 Communication from the Commission COVID-19: Guidance on the implementation of relevant EU provisions in the area of asylum and return procedures and on resettlement, op. cit., note 10, p. 10.

68 Human Mobility and Human Rights in the Covid-19 Pandemic: Principles of Protection for Migrants, Refugees and Other Displaced Persons, International Journal of Refugee Law, Vol. 20, No. 20, p. 8.

69 Alemi et al., op. cit., note 58, p. 510.

70 European Centre for Disease Prevention and Control, Guidance on infection prevention and control of coronavirus disease (COVID-19) in migrant and refugee reception and detention centres in the EU/EEA and the United Kingdom, June 2020, Stockholm, 2020, pp. 5-17. 
come. Leaving aside the current debates on the general effectiveness of the new solutions and whether the Pact represents compromises that "may come at the cost of an ambitious and humane migration and asylum policy", ${ }^{71}$ the focus will be exclusively on Covid-19 and provisions relevant for future pandemics. In that regard, the first part of the section will offer an overview of Covid-19 reference in the documents that comprise the Pact and an assessment of whether the challenges and experiences faced throughout the two preceding phases of the pandemic have been properly taken into account (4.1.). An analysis will follow of the most relevant provisions of the Proposal for a Regulation on screening and the Proposal for a Regulation on crisis and force majeure, with a view to exploring the potential pitfalls and consequences for persons in need of international protection (4.2.).

\subsection{Taking Covid-19 seriously or for granted - referral to Covid-19 in instruments that make up the Pact}

Contrary to the position of certain authors who claim that Covid-19 not only "delayed publication of the New Pact" but also "proved a game changer" for future EU asylum policy, ${ }^{72}$ such an influence cannot be inferred from the Pact's scarce referral to Covid-19. Instead, it appears that learnings of the Covid-19 experiences have been integrated in an insufficient manner and with the focus on the interests of the Member States, not those of persons seeking international protection. ${ }^{73}$ Referral to the Covid-19 pandemic is present in the introductory parts of the instruments that the Pact consists of.

Proposal for a Regulation on asylum and migration management, which is supposed to replace the Dublin III Regulation, only acknowledges "the challenges for Member States' authorities in ensuring the safety of applicants and their staff

71 Neidhart, A.-H., Sundberg Diez, O., The Upcoming New Pact on Migration and Asylum: Will it be up to the Challenge?, European Migration and Diversity Programme, Discussion Paper, April 2020, p. 4-7, [https://www.epc.eu/en/Publications/The-upcoming-New-Pact-on-Migration-and-AsylumWill-it-be-up-to-the-ch-327210], Accessed 14 April 2021. Carrera questions whether the EU actually needed a pact at such an advanced stage of European integration. Carrera, S., Whose Pact? The Cognitive Dimensions of the New EU Pact on Migration and Asylum, CEPS Policy Insights, No. 2020-22, p. 1, [https://www.ceps.eu/wp-content/uploads/2020/09/PI2020-22-New-EU-Pact-on-Migration-andAsylum.pdf], Accessed 15 April 2021. Görentas criticizes the Pact for trying to keep people out of the EU zone, for aiming at accelerating the procedures and making the return process easier, as well as for focusing on the external dimension of the problem by focusing on the cooperation with third states. Görentas, A., From EU-Turkey Statement to New Pact on Migration and Asylum: EU's Response to $21^{\text {st }}$ Century's Humanitarian Crisis, International Journal of Afro-Eurasian Research, December 2020, pp. 29-31.

72 Crawley, op. cit., note 47, p. 8.

73 Arnoux-Bellavitis, op. cit., note 49, p. 10. 
when facing the Covid-19 crisis", and the emerging necessity, "in the context of the coronavirus pandemic" to "avoid humanitarian crises" through "a system of compulsory solidarity that includes relocation and the need for long-term solutions and strong solidarity on asylum measures" ${ }^{74}$ However, such proclamations do not appear to be of much significance for two main reasons. Firstly, they are rather abstract, of programmatic character and with no practical meaning. Secondly, they seem to have been inserted subsequently, with a simple and declaratory purpose of linking the adopted solutions to the exigencies of the pandemic, although mechanisms provided therein, such as a system of compulsory solidarity, were not initially designed based on experiences gained in the context of Covid-19 pandemic.

Covid-19 experiences have been considered to a greater extent in the Proposal for a Regulation on screening. In its introductory part, the Proposal states that the Schengen Borders Code provides for no specific obligation concerning medical checks on third-country nationals, that it is "important to identify at the earliest stage possible all those in need of immediate care" and that "the recent outbreak of Covid-19 also shows the need for health checks in order to identify persons requiring isolation on public health grounds" ${ }^{75}$ It thus may be concluded that due to the Covid-19 crisis, health screenings were introduced in addition to the screenings that were initially supposed to encompass identity identification and safety reasons only.

The Pact seems to comprise the pandemic to the greatest extent in the Proposal for a Regulation on crisis and force majeure. ${ }^{76}$ Differentiating between two possibilities that may unable the regular functioning of the EU asylum system - situations of crisis and force majeure - the Proposal qualifies the situation experienced due to the Covid-19 pandemic as force majeure. However, if one considers various emergency and restrictive measures taken by the EU Member States during the first two stages of the pandemic, it is highly questionable whether the solutions provided in the Proposal will be adequate and sufficient. Namely, the only alteration allowed by the Proposal in times of force majeure consists in the extension

\footnotetext{
74 Proposal for a Regulation of the European Parliament and of the Council on asylum and migration management and amending Council Directive (EC) 2003/109 and the proposed Regulation (EU) XXX/XXX [Asylum and Migration Fund], Brussels, 23 September 2020, COM/2020/610 final. Similar referral to Covid-19 is contained in the Amended proposal for a Regulation of the European Parliament and of the Council establishing a common procedure for international protection in the Union and repealing Directive 2013/32/EU, Brussels, 23 September 2020, COM/2020/611 final.

75 Proposal for a Regulation on screening, note 4.

76 Proposal for a Regulation on crisis and force majeure, note 3.
} 
of time limits concerning registration, ${ }^{77}$ transfers $^{78}$ and timeframes for solidarity measures ${ }^{79}$. Although the adopted solutions may serve as a strong and valid argument that derogations based on general EU law are not possible in times of pandemics since public health reasons are now properly taken into account and addressed by the relevant secondary EU legislation, it remains to be seen whether the proposed amendments to the EU asylum system will be capable of ensuring that the legislative framework deals with future situations of force majeure, or whether the practice of EU Member States will once again depart from the normative framework.

\subsection{Pandemic as a health issue - which consequences for the rights of persons in need of international protection?}

Beyond the concept of the pandemic as a force majeure, instruments that make up the Pact have adopted several solutions that, due to the experiences learned during the Covid-19 pandemic, depart from the ones contained in the current CEAS. Such changes appear to have been introduced at the back door, through addressing health issues in various contexts and with the intention to make them unnoticed. The focus is shifted from the protection of the health of an individual to the protection of public health. For example, Article 32 of the currently applicable Dublin III Regulation, dealing with the exchange of health data before a transfer is carried out, provides that the transferring Member State shall only transmit the information "after having obtained the explicit consent of the applicant and/or of his or her representative or, if the applicant is physically or legally incapable of giving his or her consent, when such transmission is necessary to protect the vital interests of the applicant or of another person". ${ }^{80}$ The Proposal for a Regulation on asylum and migration management in its Article 39, which will replace Article 32 of the Dublin III Regulation, inserts another ground for exchanging health data before a transfer is carried out - the protection of public health. Namely, Article 39 does not require the explicit consent of the applicant when "such transmission is necessary to protect public health and public security". ${ }^{81}$ The shift to public health protection as a priority, instead of a so far intended protection of the health of an applicant is even more visible in the Proposal for a Regulation on screening. Article 1 of the Proposal provides that "the screening shall also entail health checks, where appropriate, to identify persons vulnerable and in the need

\footnotetext{
77 Article 7 of the Proposal for a Regulation on crisis and force majeure.

78 Article 8 of the Proposal for a Regulation on crisis and force majeure.

79 Article 9 of the Proposal for a Regulation on crisis and force majeure.

$80 \quad$ Article 32 (2) of the Dublin III Regulation, note 38.

81 Article 39 (2) of the Proposal for a Regulation on asylum and migration management, note 74.
} 
of health care as well as the ones posing a threat to public health" ${ }^{82}$ Although the provision of Article 1 appears to consider an applicant's need for healthcare and threat to public health as equally relevant aims of the newly introduced screening procedure, a number of arguments may be advanced to challenge its main purpose and potential consequences. First of all, the introductory part of the Proposal that outlines the objectives of the screening procedure offers clear guidance as to the aims intended to be achieved through screening. Its focus is not on offering relevant health care to applicants but to ensure that "any health and security risks are quickly established". What is more, the Proposal explicitly notes that submitting applicants "to the health and security checks at the external borders" contributes to "increasing the security within the Schengen area". Secondly, if one takes into account that the screening procedure has a three-fold aim - identification, health and security check - whereas health checks are associated with security checks and not identity checks throughout the explanatory part of the Proposal, this observation may serve as another argument to identify health checks as aiming at the protection of public health, not ensuring individual health care. Thirdly, Article 1 stipulates that "those checks shall contribute to referring such persons to the appropriate procedure". However, it is not clear what may qualify as an appropriate procedure in case a person is recognized as a threat to public health. The fact that the Proposal fails to regulate this issue leaves space for different practices among the Member States and potential abuses. Finally, these considerations should also be placed in the wider context of screening as a procedure that is supposed to be carried at the border, before access to the territory of a Member State and as a pre-entry and pre-asylum procedure phase. It is difficult to imagine that adequate health care is provided and medical equipment and staff present at the border, especially in times of a pandemic. ${ }^{83}$

On the other hand, the instruments that make up the Pact failed to acknowledge many issues that the Covid-19 experience revealed. Firstly, they do not properly reflect the enhanced vulnerability of persons in need of international protection in the pandemic context. Article 39 of the Proposal for a Regulation on asylum and migration management may again serve as an example since it contains the same categories of vulnerable persons as its Dublin III Regulation counterpart and does not seem to recognize new subcategories of vulnerable applicants. The same

82 Article 1 of the Proposal for a Regulation on screening, note 4.

83 Jakulevičiene, L., Re-decoration of Existing Practices? Proposed Screening Procedures at the EU External Borders, EU Immigration and Asylum Law and Policy Blog, 27 October 2020, [https://eumigrationlawblog.eu/re-decoration-of-existing-practices-proposed-screening-procedures-at-the-eu-external-borders/], Accessed 19 March 2021. 
remark relates to the Proposal for a Regulation on screening. ${ }^{84}$ Secondly, it is not clear why the Proposal for a Regulation on crisis and force majeure differentiates between the two as regards granting immediate protection status. Namely, Article 10 of the Proposal allows the Member State to suspend the examination of applications for international protection "in respect of displaced persons from third countries who are facing a high degree of being subject to indiscriminate violence, in exceptional situations of armed conflict, and who are unable to return to their country of origin" and to grant them "immediate protection status" ${ }^{85}$ However, Article 10 applies to situations of crisis only, not to force majeure. The Proposal should be criticized for not offering a similar temporary solution in cases of force majeure as well, especially considering the fact that the Covid-19 situation led to a suspension of asylum procedures. Thirdly, they do not offer guidance for solving difficult situations that will surely arise in the future, such as the relevance of the epidemiological situation in the country to which the person is to be returned or transferred for its qualification as a safe country. ${ }^{86}$ The instruments that the Pact consists of are silent on the matter.

\section{CONCLUDING REMARKS}

The current Covid-19 crisis has once again revealed the weaknesses of the EU asylum system. Without enough time to adapt to the situation caused by the 2015 migrant crisis and a large influx of persons seeking international protection, the system was put to another difficult test. However, a threat that Covid-19 exerts on public health cannot serve as a justification for the violation of EU asylum law and well-established international and European human rights standards. Although there is room for adaptation to the so-far unexperienced health crisis, modifications of EU and national asylum practices need to stay within the applicable normative frameworks. Instead of taking the lead in coordinating the action of Member States in the field of asylum, the European Union, as straightforwardly remarked by one of its officials, opted for soft tools that were not intended to make real pressure on the Member States to enforce EU law and to control its enforcement in the context of a global pandemic. ${ }^{87}$ As to the prospects of the future rules to handle the pandemics that are yet to come or the Covid-19 situation should the virus continue to be present after the entry into force of the instruments that com-

\footnotetext{
84 Recital 26 of the Proposal for a Regulation on screening.

85 Article 10 of the Proposal for a Regulation on crisis and force majeure, note 3.

86 Certain authors draw a parallel with the outbreak of Ebola when the UNHCR made a recommendation to take into account the current situation in the countries affected by Ebola before returning persons. Arnoux-Bellavitis, op. cit., note 49, pp. 14-15.

87 Ibid., p. 10.
} 
prise the New Pact on Migration and Asylum, it is doubtful whether the problems experienced during the Covid-19 crisis will be adequately addressed. Instead, the old problems seem to still be unresolved, whereas the newly emerged ones have not acquired the proper treatment. The EU asylum law and policy appear to constantly be lagging behind the real-life scenarios. As correctly remarked by Tsourdi, "until there is a permanent redesign of the CEAS, it will arguably be impossible to realize the legally binding principle of solidarity and to ensure human health and dignity, in the time of coronavirus and beyond". ${ }^{88}$

\section{REFERENCES}

\section{BOOKS AND ARTICLES}

1. Alemi, Q., Stempel, C., Siddiq H. \& Kim, E., Refugees and COVID-19: achieving a comprehensive public health response, Bulletin of the World Health Organization, Vol. 98, 2020, pp. 510-510A

2. Crawley, H., The Politics of Refugee Protection in a (Post)Covid-19 World, Social Sciences, Vol. 10, 2021, pp. 1-14

3. Danish Refugee Council, A Restriction of Responsibility-Sharing: Exploring the Impact of Covid-19 on the Global Compact on Refugees, Copenhagen, October 2020, pp. 1-33

4. European Asylum Support Office, Covid-19 Emergency Measures in Asylum and Reception Systems, Issue No. 2, 15 July 2020, pp. 1-15

5. European Centre for Disease Prevention and Control, Guidance on infection prevention and control of coronavirus disease (COVID-19) in migrant and refugee reception and detention centres in the EU/EEA and the United Kingdom, June 2020, Stockholm, 2020

6. European Council on Refugees and Exiles, Covid-19 Measures related to Asylum and Migration across Europe, Information Sheet No. 8, April 2020, pp. 1-7

7. European Council on Refugees and Exiles, Derogating from EU Asylum Law in the Name of "Emergencies": The Legal Limits Under EU Law, Legal Note No. 6, 2020, pp. 1-11

8. Fundamental Rights Agency, Coronavirus Pandemic in the EU - Fundamental Rights Implications, Bulletin No. 1, April 2020, pp. 1-60

9. Görentas, A., From EU-Turkey Statement to New Pact on Migration and Asylum: EU's Response to $21^{\text {st }}$ Century's Humanitarian Crisis, International Journal of Afro-Eurasian Research, December 2020, pp. 25-33

10. Guadagno, L., Migrants and the Covid-19 Pandemic: An Initial Analysis, Migration Research Series No. 60, International Organization for Migration, Geneva, 2020

11. Human Mobility and Human Rights in the Covid-19 Pandemic: Principles of Protection for Migrants, Refugees and Other Displaced Persons, International Journal of Refugee Law, Vol. 20, No. 20, pp. 1-10

${ }_{88}$ Tsourdi, op. cit., note 48, p. 380. 
12. Ippolito, F.; Velluti, S., The Relationship between the CJEU and the ECtHR: the Case of Asylum, in: Dzehtsiarou, K.; Konstadinides, T.; O’Marea, N. (eds), Human Rights Law in Europe - The Influence, Overlaps and Contradictions of the EU and the ECHR, Routledge, 2014

13. Jauhiainen, J., Biogeopolitics of Covid-19: Asylum-Related Migrants at the European Union Borderlands, Tijdschrift voor Economische en Sociale Geografie, Vol. 111, No. 3, 2020, p. 260-274

14. Jovičić, S., Covid-19 Restrictions on Human Rights in the Light of the Case-law of the European Court of Human Rights, ERA Forum, Vol. 21, 2021, pp. 545-560

15. Kelly, S.B., The European Union Obligation: Member States must not Neglect the Consequences of Covid-19 to the Disadvantaged Asylum Seekers and Refugees, HAPSc Policy Briefs Series, Vol. 1, No. 1, 2020, pp. 209-218

16. Kluge, H. H.; Jakab, Z.; Bartovic, J.; D’Anna, V.; Severoni, S., Refugee and Migrant Health in the Covid-19 Response, The Lancet, Vol. 395, 2020, pp. 1237-1239

17. Lanzarone, A.; Tullio, V.; Argo, A.; Zerbo, S., When a Virus (Covid-19) Attacks Human Rights: The Situation of Asylum Seekers in the Medico-Legal Setting, Medico-Legal Journal, Vol. 89, No. 1, 2021, pp. 29-30

18. Lukić-Radović, M.; Čučković, B., Dublin IV Regulation, the Solidarity Principle and Protection of Human Rights - Step(s) Forward or Backward?, in: Duić, D.; Petrašević, T., (eds), EU Law in Context - Adjustment to Membership and Challenges of the Enlargement, EU and Comparative Law Issues and Challenges Series, University Josip Juraj Strossmayer, Osijek, 2018, pp. 10-30

19. Marin. L., The Covid-19 Crisis and the Closure of External Borders: Another Stress-test for the Challenging Construction of Solidarity Within the EU?, European Papers, Vol. 5, No. 2, 2020, pp. 1071-1086

20. Mukumbang, F., Are Asylum Seekers, Refugees and Foreign Migrants Considered in the Covid-19 Vaccine Discourse?, BMJ Global Health, 2020, pp. 1-4

21. Rizcallah, C., Facing the Refugee Challenge in Europe: A Litmus Test for the European Union - A Critical Appraisal of the Common European Asylum System Through the Lens of Solidarity and Human Rights, European Journal of Migration and Law, Vol. 21, No. 2, pp. 238-260

22. Spadaro, A., Covid-19: Testing the Limits of Human Rights, European Journal of Risk Regulation, Vol. 11, No. 2, 2020, pp. 317-325

23. Triandafyllidou, A., Commentary: Spaces of Solidarity and Spaces of Exception at the Times of Covid-19, International Migration, Vol. 58, No. 3, 2020, pp. 261-263

24. Tsourdi, E., Covid-19, Asylum in the EU, and the Great Expectations of Solidarity, International Journal of Refugee Law, Vol. 32, No. 2, 2020, pp. 374-380

25. Tzevelekos, V.; Dzehtsiarou, K., Normal as Usual? Human Rights in Times of Covid-19,

26. Veizis, A., Commentary: "Leave No One Behind" and Access to Protection in the Greek Islands in the Covid-19 Era, International Migration, Vol. 58, No. 3, 2020, pp. 264-266

\section{COURT OF JUSTICE OF THE EUROPEAN UNION}

1. Case 72/83 Campus Oil Limited and others $v$ Minister for Industry and Energy and others [1984] ECR $1984-02727$ 
2. Joined Cases C715/17, C718/17 and C719/17 Commission v. Poland, Hungary and Czech Republic, [2020] ECLI:EU:C:2020:257

\section{ECtHR}

1. Lawless $v$ Ireland No. 3 (1961) 1 EHRR 15

2. Denmark, Norway, Sweden and the Netherlands v. Greece (1968), Apps. Nos. 3321/67, $3322 / 67,3323 / 67$ and 3344/67

3. N. $v$ the United Kingdom (2008), App. No. 26565/05

4. Tabesh $v$ Greece (2009), App. No. 8256/07

5. Louled Massoud v Malta (2010), App. No. 24340/08

6. M.S.S. v. Belgium and Greece (2011) 53 EHRR 2

7. Sharifi and others $v$ Italy and Greece (2014), App. No. 16643/09

8. Tarakhel $v$ Switzerland (2014), App. No. 29217/12

9. Başv Turkey (2020), App. No. 66448/17

\section{EU LAW}

1. Consolidated version of the Treaty on the Functioning of the European Union [2012] OJ C 326, pp. 47-390

2. Regulation (EU) No 604/2013 of the European Parliament and of the Council establishing the criteria and mechanisms for determining the Member State responsible for examining an application for international protection lodged in one of the Member States by a thirdcountry national or a stateless person (recast) [2013] OJ L 180, pp. 31-59

3. Directive 2013/32/EU of the European Parliament and of the Council on common procedures for granting and withdrawing international protection [2013] OJ L 180, pp. 60-95

4. Directive 2013/33/EU of the European Parliament and of the Council laying down standards for the reception of applicants for international protection (recast) [2013] OJ L 180, pp. 96-116

5. Regulation (EU) 2016/399 of the European Parliament and of the Council of 9 March 2016 on a Union Code on the rules governing the movement of persons across borders (Schengen Borders Code) [2016] OJ L 77, pp. 1-52

6. Communication from the Commission to the European Parliament, the European Council and the Council, Covid-19: Temporary Restriction on Non-Essential Travel to the EU, Brussels, 16 March 2020, COM/2020/115 final

7. European Commission, Covid-19 Guidelines for border management measures to protect health and ensure the availability of goods and essential services (2020) OJ C 86/I, pp. 1-4

8. Communication from the Commission to the European Parliament, the Council, the European Economic and Social Committee and the Committee of the Regions on a New Pact on Migration and Asylum, Brussels, 23 September 2020, COM/2020/609 final

9. Proposal for a Regulation of the European Parliament and of the Council on asylum and migration management and amending Council Directive (EC) 2003/109 and the proposed 
Regulation (EU) XXX/XXX [Asylum and Migration Fund], Brussels, 23 September 2020, $\mathrm{COM} / 2020 / 610$ final

10. Proposal for a Regulation addressing situations of crisis and force majeure in the field of migration and asylum, Brussels, 23 September 2020, COM/2020/613 final

11. Proposal for a Regulation introducing a screening of third country nationals at the external borders, and amending Regulations (EC) No 767/2008, (EU) 2017/2226, (EU) 2018/1240 and (EU) 2019/817, Brussels, 23 September 2020, COM/2020/612 final

12. Amended proposal for a Regulation of the European Parliament and of the Council establishing a common procedure for international protection in the Union and repealing Directive 2013/32/EU, Brussels, 23 September 2020, COM/2020/611 final

\section{WEBSITE REFERENCES}

1. Arnoux-Bellavitis, M., The Influence of Covid-19 on the European Asylum and Migration Policy - Making Health a Priority while Ensuring the Respect for Fundamental Rights, Institute of European Democrats, 2020, pp. 1-22, [https://www.iedonline.eu/download/geopoliticsvalues/26-Arnoux-Bellavitis_-_The_influence_of_covid_19_on_the_EU_asylum_and_migration_policy-FINAL.pdf], Accessed 1 April 2021

2. Carrera, S., Whose Pact? The Cognitive Dimensions of the New EU Pact on Migration and Asylum, CEPS Policy Insights, No. 2020-22, pp. 1-18, [https://www.ceps.eu/wp-content/ uploads/2020/09/PI2020-22-New-EU-Pact-on-Migration-and-Asylum.pdf], Accessed 1 April 2021

3. Carlucci, M., Europe, Migration and Covid-19: Turning Pointor Consolidation of the Status Quo?, International Development Research Network, 2020, pp. 1-11 [https://static1.squarespace. com/static/5e8ce9ff629cbb272fd0406f/t/5ed54e91bd306477f6ca4739/1591037588073/ Europe\%2C+Migration+and+Covid-19.pdf], Accessed 14 January 2021

4. Conclusions by the President of the European Council following the video conference on COVID-19. 10 March 2020, [https://www.consilium.europa.eu/en/press/press-releases/2020/03/10/statement-by-the-president-of-the-european-council-following-the-videoconference-on-covid-19/], Accessed 6 March 2021

5. Dimitriadi, A., The Future of European Migration and Asylum Policy post Covid-19, FEPS Covid Response Papers, Issue No. 7, July 2020, pp. 2-9 [https://www.feps-europe.eu/attachments/publications/feps\%20covid\%20response\%20migration\%20asylum.pdf], Accessed 12 January 2021

6. International Commission of Jurists, The Impact of Covid-19 related measures on human rights of migrants and refugees in the EU, Briefing paper, 26 June 2020, pp. 1-20, [https://www. icj.org/wp-content/uploads/2020/06/Covid19-impact-migrans-Europe-Brief-2020-ENG. pdf], Accessed 14 January 2021

7. Jakulevičiene, L., Re-decoration of Existing Practices? Proposed Screening Procedures at the EU External Borders, EU Immigration and Asylum Law and Policy Blog, 27 October 2020, [https://eumigrationlawblog.eu/re-decoration-of-existing-practices-proposed-screeningprocedures-at-the-eu-external-borders/], Accessed 19 March 2021 
8. Migration: Commission takes action to find solutions for unaccompanied migrant children on Greek islands, European Commission, Press release, Brussels, 6 March 2020 [https:// ec.europa.eu/commission/presscorner/detail/en/ip_20_406], Accessed 10 February 2021

9. Neidhart, A.-H., Sundberg Diez, O., The Upcoming New Pact on Migration and Asylum: Will it be up to the Challenge?, European Migration and Diversity Programme, Discussion Paper, April 2020, pp. 1-12, [https://www.epc.eu/en/Publications/The-upcoming-New-Pact-onMigration-and-Asylum-Will-it-be-up-to-the-ch 327210], Accessed 4 April 2021

10. Press statement by President von der Leyen on the New Pact on Migration and Asylum, Brussels, 23 September 2020, [https://ec.europa.eu/commission/presscorner/detail/en/ statement_20_1727], Accessed 5 January 2021

11. Rasche, L., Four Implications of the Covid-19 Pandemic for the EU's Asylum and Migration Policy, Policy Brief, 24 July 2020, pp. 1-6, [https:/www.hertie-school.org/fileadmin/2_Research/1_About_our_research/2_Research_centres/6_Jacques_Delors_Centre/Publications/20200724_Covid-19_Migration-Rasche.pdf], Accessed 25 March 2021

12. Russack, S., EU Crisis Response in Tackling Covid-19 - Views from the Member States, European Policy Institutes Network Report, 20 April 2020, pp. 1-16, [https://www.clingendael. org/sites/default/files/2020-04/Report_EU_crisis_response_April_2020.pdf], Accessed 25 March 2021 